I.R.

The attached version of the paper by M. Piochi, L. Pappalardo and G. De Astis, «Geochemical and isotopical variations within the Campanian Comagmatic Province: implications on magma source composition», fully replaces the one published in Annals of Geophysics, 2004, vol. 47, n. 4, pp. 1485-1499.

Editrice Compositori 


\title{
Geochemical and isotopical variations within the Campanian Comagmatic Province: implications on magma source composition
}

\author{
Monica Piochi, Lucia Pappalardo and Gianfilippo De Astis \\ Osservatorio Vesuviano, Istituto Nazionale di Geofisica e Vulcanologia, Napoli, Italy
}

\begin{abstract}
A spatial variation in chemical and isotopical composition is observed between the volcanoes belonging to the Campanian Comagmatic Province. At a given $\mathrm{MgO}$ content, magmas from volcanic islands (Procida and Ischia) are enriched in $\mathrm{Ti}$, Na, depleted in $\mathrm{La}, \mathrm{Ba}, \mathrm{Rb}, \mathrm{Sr}$, Th, $\mathrm{K}$ contents, and shows lower LREE/HFSE (e.g., La/Nb = $=1-2$ ), lower $\mathrm{Sr}-\mathrm{Pb}$ isotopic ratios and higher $\mathrm{Nd}$ isotopic ratios with respect to magmas from volcanoes located inland (Campi Flegrei and Somma-Vesuvius). The observed compositional variations are explained involving two different mantle sources in the genesis of the magmas erupted in this region: a deeper asthenospheric mantle source, from which the Tyrrhenian magmas also derived and a lithospheric mantle source enriched by slabderived fluids. The contribution of the enriched-lithospheric mantle became more pronounced moving from the Tyrrhenian abyssal plain through the Italian Peninsula where it dominates, likely in response to the thickening of the lithosphere observed under the Peninsula.
\end{abstract}

Key words lithosphere-asthenosphere-Campanian Province - Tyrrhenian Basin - geochemistry

\section{Introduction}

The Campanian Plain is located between the western margin of the Apennine chain and the eastern border of the Tyrrhenian abyssal plain (fig. 1a,b). Since the Pliocene the Plain has been affected by intense extensive tectonic and magmatism (e.g., Scandone, 1979; Peccerillo and Manetti, 1985; Di Girolamo, 1987; Doglioni, 1991). At the present time the Campanian Plain

Mailing address: Dr. Monica Piochi, Osservatorio Vesuviano, Istituto Nazionale di Geofisica e Vulcanologia, Via Diocleziano 328, 80124 Napoli, Italy; e-mail: monky5@ov.ingv.it is bordered by conjugate NE-SW and NW-SE fault systems formed during the opening of the Tyrrhenian Sea. The volcanic districts of Campi Flegrei, Procida and Ischia, and the strato-volcano of Somma-Vesuvius developed on NE-SW structure lines (see Beccaluva et al., 1991, for a review).

Campanian volcanoes are among the most studied volcanoes in the world. The many papers published in the last decade (e.g., Civetta et al., 1991a,b, 1997; Civetta and Santacroce, 1992; Belkin et al., 1993; Santacroce et al., 1993; D'Antonio and Di Girolamo, 1994; Cioni et al., 1995; Orsi et al., 1995; Ayuso et al., 1998; D’Antonio et al., 1999a,b; de Vita et al., 1999; Marianelli et al., 1999; Pappalardo et al., 1999, 2002; Piochi et al., 1999; Del Moro et al., 2001; Somma et al., 2001) provide a wide data base of chemical and isotopic analyses. However the meaning of petrochemical variations 

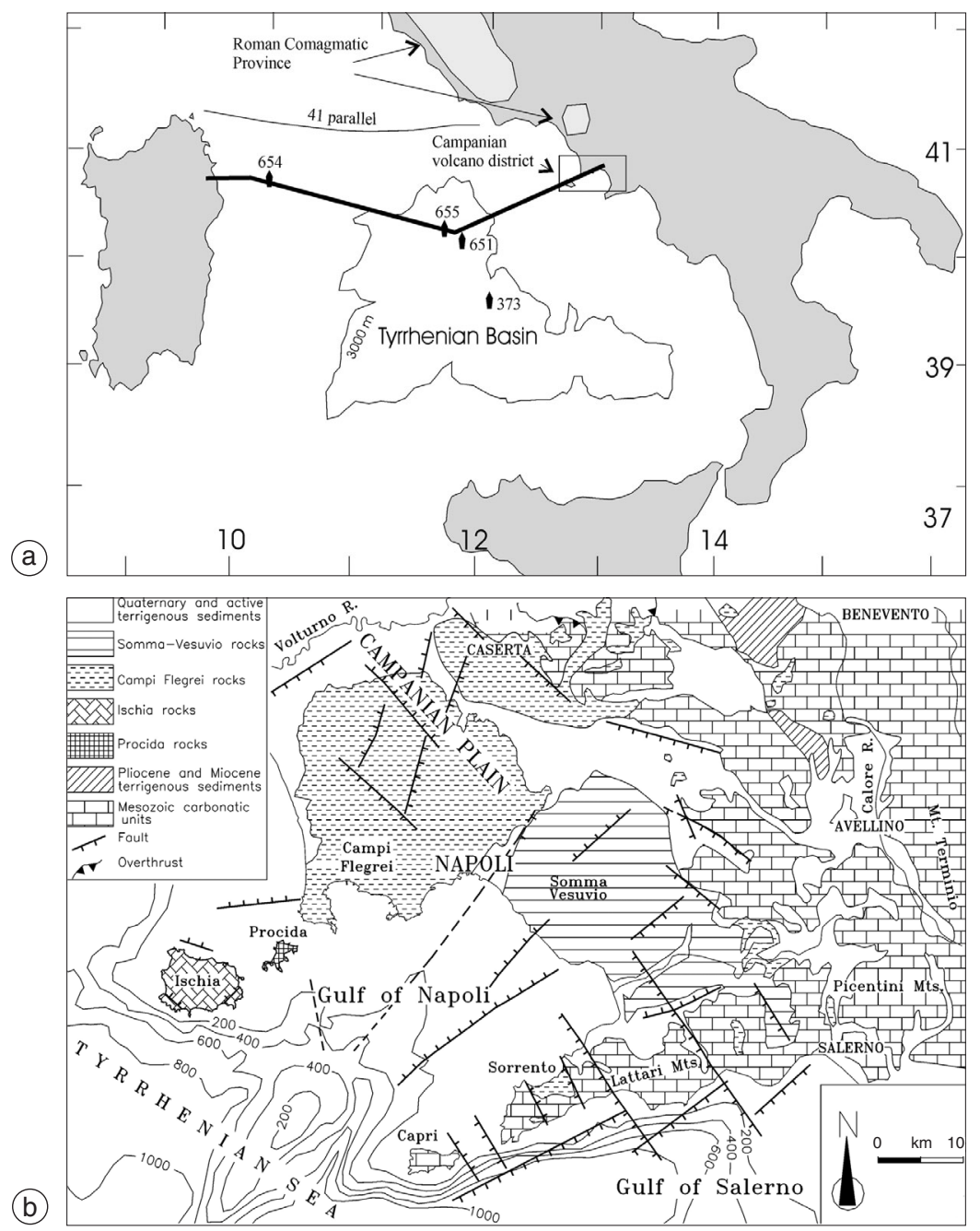

Fig. 1a,b. a) Southern Italy map showing location of the Campanian volcanic area and Tyrrhenian abissal Plain. Bold line is the cross section in fig. 6; b) geological and tectonic sketch map of the Campanian Plain showing distribution of sedimentary sequences and Campi Flegrei, Ischia, Procida and Somma-Vesuvius volcanic rocks (modified from Orsi et al., 1996).

shown by the erupted products is not completely clear, and a debate exists about the genesis and evolution of Campanian magmas and its geodynamic setting (see Turi and Taylor, 1976; Vollmer, 1976; Hawkesworth and Vollmer, 1979; Cortini and Hermes, 1981; Vollmer et al., 1981; Peccerillo and Manetti, 1985; Ellam et al., 1989; Beccaluva et al., 1991; D'Antonio et al., 1996; Ayuso et al., 1998; Peccerillo, 1999, 2001; Somma et al., 2001).

An open question about the nature of the most mafic magmas is whether they represent deep asthenospheric mantle magmas or reflects shallower imprinting acquired in the lithospheric mantle or in the crust. To shed light on this problem, our paper compares the available com- 
positional data (major-, trace-elemental, and isotopes) from rocks erupted from Campanian volcanoes both situated inland (Somma-Vesuvius and Campi Flegrei) and offshore (Procida and Ischia), with that from magmas erupted on the Thyrrenian abyssal plain. In this way, the regional chemical and isotopic variations of magmas going from east to west can be investigated in relation to the deepening of the crust - mantle boundary (Ferrucci et al., 1989) and the increase in lithospheric thickness (Cella et al., 1998) observed moving from Tyrrhenian Basin towards the Apennine Chain. We assume that if significant modification of the deep mantle magmas occurs en route to the surface and/or by the crust, then such a process should be revealed by comparing the geochemical and isotopic signatures of offshore and inland volcanic complexes.

\section{Geological setting}

The Campanian volcanoes are part of the potassic-rich Italian belt which developed on the eastern side of the Tyrrhenian Sea whose abyssal plain is composed of MORB-like basaltic rocks (Beccaluva et al., 1990). They constitute the Campanian Comagmatic Province that is distinguished from the Roman one on the basis of some important geochemical differences in the outcropping volcanics (Duschenes et al., 1986; Beccaluva et al., 1991). The two Provinces are separated by a lithospheric discontinuity corresponding to the $41^{\circ}$ parallel (fig. 1a,b) dividing two different mantle domains (Savelli and Wezel, 1979; Lavecchia, 1988; Spadini and Wezel, 1994; Bruno et al., 2000). The CrustMantle boundary beneath the Campi Flegrei and Somma-Vesuvius has been identified at 25-30 $\mathrm{km}$, whereas it rises moving westward, being at less than $25 \mathrm{~km}$ beneath Ischia (Corrado and Rapolla, 1981; Ferrucci et al., 1989) and less than $10 \mathrm{~km}$ in the Central Tyrrhenian Basin (Duschenes et al., 1986; Gueguen et al., 1997). The nature of the lower crust is not known although the correlation with the Southern Apennine structures (Finetti and Morelli, 1973; Schutte, 1978; Scandone, 1982) and petrological studies on xenoliths (Pappalardo et al., 2002) suggest that it should be a Hercynian basement.
The upper crust consists of a succession of Triassic to Cretaceous limestones and dolomites overlain by Miocene arenaceous and/or flysch sediments, or by pyroclastic rocks (D'Argenio et al., 1973; Ippolito et al., 1975) cropping out in the Apennine Chain. This succession, which is displaced down to $4000 \mathrm{~m}$ depth in the Campanian Plain (D'Argenio et al., 1973; Ippolito et al., 1975; D'Argenio et al., 1987), has been drilled at depths of about $2.4 \mathrm{~km}$ beneath the SommaVesuvius (Brocchini et al., 2001) and has been identified by seismic profiles at depths of more than 3-4 km in the Gulf of Napoli and Pozzuoli (Finetti and Morelli, 1974; Bruno et al., 1998).

The Campi Flegrei, and the Ischia and Procida islands are volcanic fields of the Phlegraean Volcanic District characterized by several monogenic vents that produced both low-energy explosive and effusive eruptions. High-volume ignimbrite eruptions also occurred in the area at least from $200 \mathrm{kyr}$ BP, some of these eruptions generated large caldera structures at Campi Flegrei and Ischia (e.g., Rosi and Sbrana, 1987; Vezzoli, 1988; Orsi et al., 1996; De Vivo et al., 2001). Volcanism is broadly coeval at Campi Flegrei and Ischia where the onset of volcanic activity is dated before $80 \mathrm{kyr}$ and $150 \mathrm{kyr}$ and lasted up to 1532 A.D. and 1302 A.D., respectively (Alessio et al., 1971; Gillot et al., 1982). Volcanic activity occurred from about $80 \mathrm{kyr}$ up to $14 \mathrm{kyr}$ at Procida (see Rosi et al., 1988; Beccaluva et al., 1991). Somma-Vesuvius is a strato-volcano that experienced lava flows and small-to-high scale energy eruptions; the oldest Somma-Vesuvius volcanic products are dated at $0.4 \mathrm{Myr}$ (Brocchini et al., 2001) and the last eruption occurred in 1944 A.D.

At the present time, Campi Flegrei, Ischia and Somma-Vesuvius are the site of widespread fumaroles and thermal springs, as well as seismic activity. Furthermore, bradyseismic phenomena, characterized by ground movements and seismic activity affected Campi Flegrei in 1972, 1984 and 2000 A.D.

\section{Petrological setting}

The Campanian volcanic rocks belong to the KS series of Appleton (1972) and range in composition from shoshonites to trachy-phonolites. 
The latter are the most widespread products. At Somma-Vesuvius milddly to highly undersaturated rocks belonging to the HKS of Appleton (1972), ranging in composition from alkalibasalt to phonolite, also occur. The Campanian rocks have nearly aphyric to strongly porphyritic texture: generally the porphyriticity is higher in Somma-Vesuvius with respect to Phlegraean rocks, and in Ischia with respect to the Campi Flegrei and Procida rocks. In the KS evolved rocks K-feldspar, plagioclase, Fe-rich diopside, magnetite and biotite represent typical minerals. In the least evolved ones, K-feldspar and biotite are absent, olivine and $\mathrm{Mg}$-rich diopside join the other phases reported. Apatite is the most common accessory crystal. The least evolved HKS rocks from Somma-Vesuvius contain olivine, plagioclase and Fe-rich and $\mathrm{Mg}$-poor diopside. Leucite is the most common mineral in the most evolved rocks. Garnet and phlogopite are very common accessory phases.

Major and trace element and $\mathrm{Sr}-\mathrm{Nd}-\mathrm{Pb}$ isotope variations within the Campanian rocks have been attributed to complex evolutionary processes involving magmas chamber refilling, magmas mixing and crustal assimilation by mantle-derived magmas in a multi-depth magmatic system (e.g., Cioni et al., 1995; Ayuso et al., 1998; D'Antonio et al., 1999a; Pappalardo et al., 1999, 2002; Piochi et al., 1999; Del Moro et al., 2001). In particular, the existence of both deep and shallower crustal reservoirs has been proposed in several studies of the Campanian volcanoes (Belkin et al., 1985; Cortini et al., 1985; Piochi et al., 1999; Marianelli et al., 1999; Pappalardo et al., 2002; Lima et al., 2003; De Astis et al., 2004). Inside the Phlegraean Volcanic District, the deeper reservoir was tapped by a regional fault system during eruptions extruding the least evolved magmas that mingled during ascent with magmas evolving at shallower depth (De Astis et al., 2004; and references therein). Compositional differences have been detected in volcanic rocks from Ischia island with respect to those from Campi Flegrei and Somma-Vesuvius (e.g., Turi and Taylor, 1976; Cortini and Hermes, 1981; Paterne et al., 1988; Vezzoli, 1988; Pappalardo et al., 1999), although their meaning has not been thoroughly investigated.
The source of magmastism has been located in a mantle variably enriched in incompatible elements, radiogenic $\mathrm{Sr}$ and unradiogenic $\mathrm{Nd}$ (e.g., Hawkesworth and Vollmer, 1979; Peccerillo and Manetti, 1985; Beccaluva et al., 1991; D'Antonio et al., 1996; Ayuso et al., 1998; D’Antonio et al., 1999b; Peccerillo, 1999, 2001). Debate exists about the agent of enrichment that should be i) mantle-derived fluids in a intra-plate tectonic setting (e.g., Cundari, 1980; Vollmer, 1989) or ii) fluids or melts released by an undergoing oceanic slab (e.g., Di Girolamo, 1978, 1987; Hawkesworth and Vollmer, 1979; Peccerillo and Manetti, 1985; Peccerillo, 1990, 2001; Beccaluva et al., 1991; Serri et al., 1993; D’Antonio et al., 1996) which modify a OIB-type (e.g., Beccaluva et al., 1991) or a MORB-type mantle (e.g., D'Antonio et al., 1996).

Recently, the discovery of xenoliths of crustal origin in the least evolved ${ }^{87} \mathrm{Sr}$-enriched rocks from the Campi Flegrei strongly contributed to highlight both the role of crustal contamination in magmas composition and the existence of a homogeneous mantle source beneath the Phlegraean area (Pappalardo et al., 2002). The nature of xenoliths allows recognition of at least two crustal levels of contamination the deeper of which located in the Hercynian basement. Following Cecchetti et al. (2001), this depth is about $10-15 \mathrm{~km}$ and is similar to that proposed by Belkin et al. (1985), Belkin and De Vivo (1993), Marianelli et al. (1999), Lima et al. (2003) and by Zollo et al. (1996) for Somma-Vesuvius. Crustal contamination has been proposed also at Somma-Vesuvius on the basis of mineral chemistry, fluid inclusion and isotope data (e.g., Savelli, 1968; Fulignati et al., 1995, 1998; Gilg et al., 1999, 2001; Del Moro et al., 2001; Pappalardo et al., 2004).

\section{Data presentation}

\subsection{Geochemistry}

Major and trace elements have been published in previous papers (Civetta et al., 1991a,b, 1997; Civetta and Santacroce, 1992; Orsi et al., 1992, 1995, 1996; Caprarelli et al., 
1993; Belkin et al., 1993; Santacroce et al., 1993; D'Antonio and Di Girolamo, 1994; Cioni et al., 1995; Ayuso et al., 1998; D’Antonio et al., 1999a,b; de Vita et al., 1999; Marianelli et al., 1999; Pappalardo et al., 1999, 2002; Piochi et al., 1999; Del Moro et al.,
2001; Somma et al., 2001); the database is available on request from the authors. Figure 2 shows selected major and trace element variation diagrams versus $\mathrm{SiO}_{2}$. These diagrams, although sometimes scattering mainly as consequence of different analytical procedures
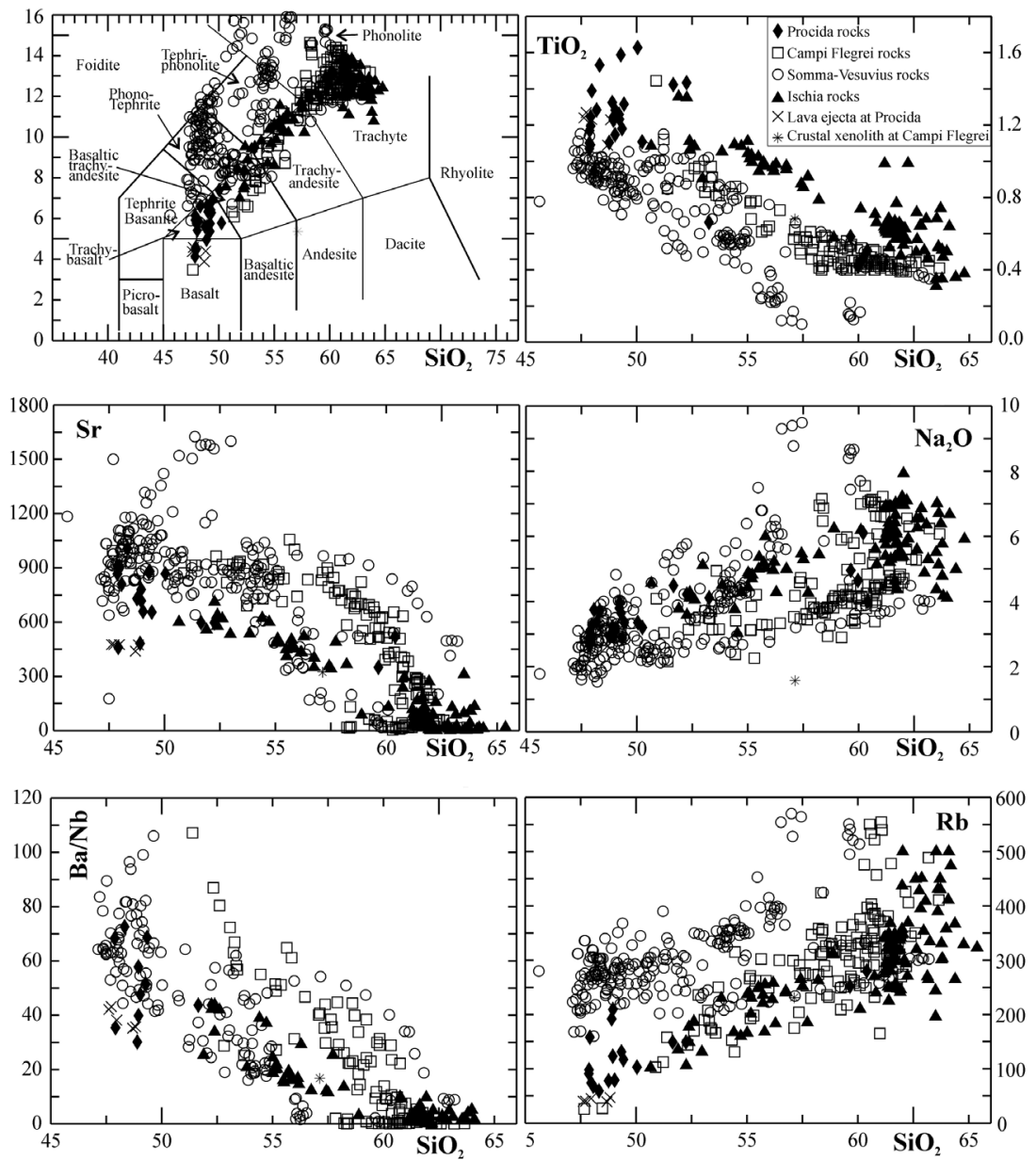

Fig. 2. Selected major and trace elements variation diagrams versus $\mathrm{SiO}_{2}$. Source of data: Civetta et al. (1991a,b, 1997); Civetta and Santacroce (1992); Orsi et al. (1992, 1995, 1996); Caprarelli et al. (1993); Belkin et al. (1993); Santacroce et al. (1993); D'Antonio and Di Girolamo (1994); Cioni et al. (1995); Ayuso et al. (1998); D'Antonio et al. (1999a,b); de Vita et al. (1999); Marianelli et al. (1999); Pappalardo et al. (1999, 2002); Piochi et al. (1999); Del Moro et al. (2001); Somma et al. (2001). Symbols: $\times=$ lava ejecta in Solchiaro deposits (Procida); full diamonds: Procida samples; full triangles = Ischia samples; open squares = Campi Flegrei samples; open circles $=$ Vesuvius samples; $*=$ lithic clasts in Campi Flegrei deposits 
(ICP or XRF) and crystal contents (see previous section), display increasing $\mathrm{Na}_{2} \mathrm{O}$ content and decreasing $\mathrm{P}_{2} \mathrm{O}_{5}, \mathrm{TiO}_{2}, \mathrm{MgO}$, and $\mathrm{Fe}_{2} \mathrm{O}_{3}$ contents. $\mathrm{K}_{2} \mathrm{O}$ increases up to about $60 \mathrm{wt} \%$ of $\mathrm{SiO}_{2}$ and then decreases; $\mathrm{MnO}$ decreases up to 60 wt $\%$ of $\mathrm{SiO}_{2}$ then became strongly scattered. The most mafic compositions $(\mathrm{MgO}>$ $>9 \mathrm{wt} \%$ ) are represented just by some rocks from Procida. La, Ce, Rb, Y, Zr, Nb and Th increase by factors up to 2 from mafic to silic compositions; $\mathrm{Sc}, \mathrm{Cr}, \mathrm{Co} \mathrm{Ni}, \mathrm{Eu}, \mathrm{V}$ show an opposite trend. $\mathrm{Ba}$ is firstly strongly scattered in the range $45-55 \mathrm{wt} \%$ of $\mathrm{SiO}_{2}$ content and then decreases, whereas in the same range, $\mathrm{Sr}$
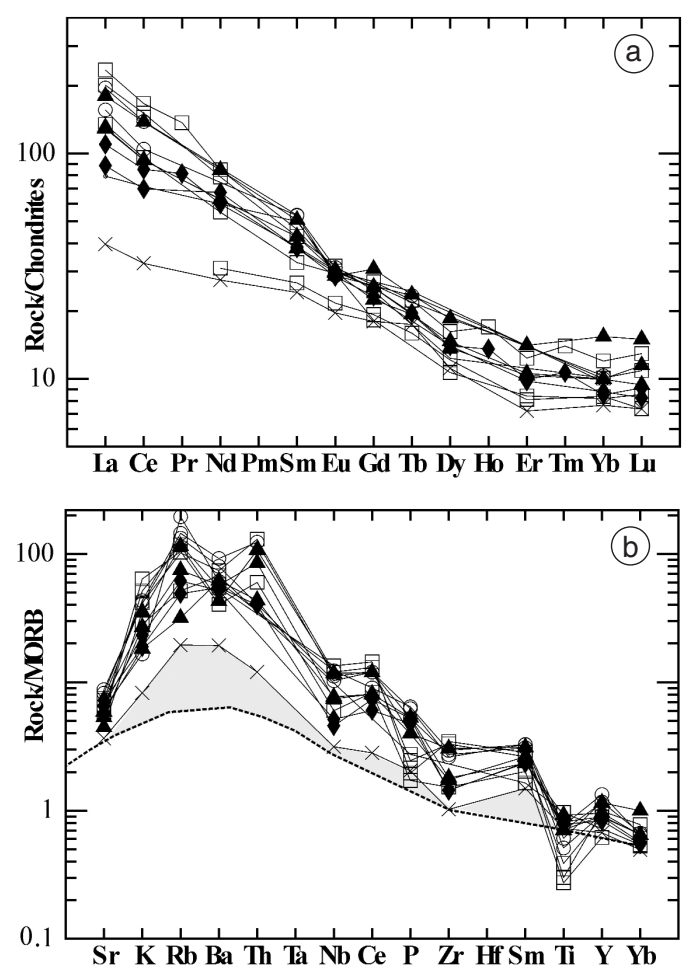

Fig. 3a,b. a) REE patterns for selected Campanian magmas. Normalization on the basis of Nakamura (1974); b) trace elements distribution for selected Campanian magmas. Normalization on the basis of Pearce (1983). Symbols as in fig. 2. Dashed area indicates the intra-plate component following Thorpe et al. (1984). is initially constant and then decreases. Some samples from Somma-Vesuvius, related to a single eruption, define a separate array. The most evolved rocks from Campi Flegrei and Ischia show a steep enrichment in some incompatible elements (e.g., Th, REE).

Magmas erupted at Somma-Vesuvius, define a trend depleted in $\mathrm{Ti}, \mathrm{Mg}, \mathrm{Fe}, \mathrm{P}, \mathrm{Ca}, \mathrm{V}$ and enriched in $\mathrm{Al}, \mathrm{Nb}, \mathrm{Rb}, \mathrm{Th}, \mathrm{K}$, Na with respect to the Campanian trends (fig. 2). Procida, Campi Flegrei and Ischia magmas show chemical similarity, although, at a given $\mathrm{SiO}_{2}$ content, the Ischia magmas are enriched in $\mathrm{Ti}, \mathrm{Na}, \mathrm{Nb}, \mathrm{Yb}$ and depleted in $\mathrm{Ba}, \mathrm{Sr}, \mathrm{Th}, \mathrm{Eu}$ (fig. 2). However, in the least evolved rocks $(\mathrm{MgO}>6 \mathrm{wt} \%)$ from each volcanic district display reasonably constant ratios between elements with similar degree of incompatibility. For example (fig. 2), $\mathrm{La} / \mathrm{Ce}, \mathrm{Th} / \mathrm{Zr}$ and, $\mathrm{Nb} / \mathrm{Zr}$ are $0.5 \pm 0.1,0.06 \pm 0.04,0.14 \pm 0.06$, respectively. Some variations could be related to different analytical procedures and analytical error.

REE and other trace element distributions are reported in fig. 3a,b, where Campanian magmas of similar degrees of evolution $(3.8<\mathrm{MgO}<5 \mathrm{wt} \%)$ are compared. The only exception in these spiderdiagrams are the Campi Flegrei rocks with $\mathrm{MgO}$ contents less than 3.8 wt\% that Pappalardo et al. (2002) suggest are representative of the least-contaminated magmas. REE and trace element patterns are roughly sub-parallel to each other with no difference between products from each district. Generally, all selected samples show enrichment in LREEs and other incompatible trace elements ( $\mathrm{Rb}, \mathrm{K}, \mathrm{Th}, \mathrm{Sr}, \mathrm{Ba})$, and minor enrichment in more compatible elements such as HREE and Y. Negative $\mathrm{Nb}$ and Eu anomalies characterize the Campanian rocks, although their amplitude decreases toward the less evolved samples. Mafic rocks from Procida define a less enriched pattern, have lower REE and incompatible trace element contents coherently with their more primitive nature, and no detectable Eu anomaly.

\subsection{Isotope geochemistry}

${ }^{87} \mathrm{Sr} /{ }^{86} \mathrm{Sr}$ and ${ }^{143} \mathrm{Nd} /{ }^{144} \mathrm{Nd}$ ratios are variable and depict a trend from Procida towards the 

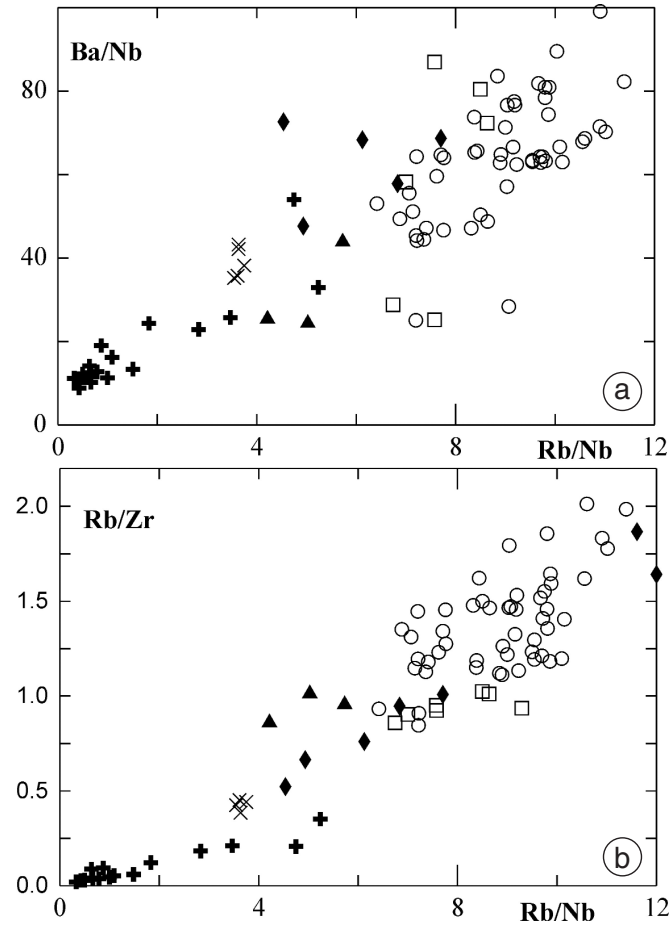

Fig. 4a,b. Selected LILE/HFSE diagrams for Campanian rocks with $\mathrm{MgO}>3.8 \%$. Symbols: full crosses $=$ Tyrrhenian samples (Beccaluva et al., 1990; Gasperini et al., 2002). Other symbols as in fig. 2.

crustal-derived xenoliths recovered in Campi Flegrei rocks (fig. 4a). Magmas erupted at Ischia are isotopically distinct from that of Somma-Vesuvius and Campi Flegrei: Sr-isotope composition ranges from 0.7060 to 0.7068 at Ischia and from 0.7068 to 0.7089 at SommaVesuvius and Campi Flegrei. ${ }^{87} \mathrm{Sr} /{ }^{86} \mathrm{Sr}$ ratios also vary from 0.7051 to 0.7060 in the Procida volcanic rocks. $\mathrm{Nd}$-isotope composition ranges from 0.51245 to 0.51265 in the Ischia rocks and from 0.51230 to 0.51265 at Campi Flegrei and Somma-Vesuvius. ${ }^{143} \mathrm{Nd} /{ }^{144} \mathrm{Nd}$ values range from 0.51255 to 0.5127 in rocks from Procida.

\section{Discussion}

The absence of «primary» magmas compositions at Campi Flegrei, Ischia, and Somma-
Vesuvius prevents knowing directly the nature of the mantle source.

Most of the mafic rocks produced in the Campanian region have much lower $\mathrm{Cr}, \mathrm{Ni}$ and $\mathrm{MgO}$ contents with respect to those indicated by Perfit et al. (1980) (500-600 ppm, 300 ppm and $6 \mathrm{wt} \%$, respectively), to have been in equilibrium with a peridotite magmas source. Some «primitive» compositions have been recognized in the lava ejecta on Procida island and on the basis of their high $\mathrm{MgO}, \mathrm{Cr}$ and $\mathrm{Ni}$ contents (10-11 wt\%, 426-610 ppm, 134-233 ppm, respectively) they were considered nearly primary magmas (D'Antonio et al., 1996, 1999b). The features of the majority of the Campanian volcanic rocks are characterized by high $\mathrm{SiO}_{2}$ contents and high porphyritic indicis, and the absence of mantle-derived xenoliths. These features suggest that the primary magmas underwent shallow-level differentiation processes after segregation from their mantle source. The isotopic variations reported above, not associated with Fractional Crystallization (FC) process in closed reservoirs, have to be produced by interactions of parental magmas with crustal rocks en route to the surface or by addition of crustal materials to the source. Therefore, as we are interested in identifying the nature of the source, we will discuss the rock features inherited by shallow-level processes and then deal with the source related features.

\subsection{Shallow level magma evolution}

Most of the chemical variations in Campanian rocks are consistent with a differentiation mechanism involving the fractionation of the observed mineral phases (FC) within closed magmatic systems. The trend defined by $\mathrm{Sr}$ and Eu respect to the silica content (fig. 2) and the existence of $\mathrm{Eu}$ anomaly in the most evolved rocks (fig. 3a,b) are consistent with the role of feldspar (the main crystal phase) crystallization during magmas evolution. The FC process is supported by the constancy of the Sr-isotopic ratios in rocks from some eruptive events at Ischia (Civetta et al., 1991b; Piochi et al., 1999), Campi Flegrei (Pappalardo et al., 1999) and Somma-Vesuvius (Ayuso et al., 1998 and refer- 
ences therein). On the other hand, variations of the isotopic compositions of magmas with time have generally been related to mixing processes between distinct parental magmas batches reaching a shallow reservoir (Cioni et al., 1995; D'Antonio et al., 1999b; Pappalardo et al., 1999; Piochi et al., 1999). New studies on Campi Flegrei (Pappalardo et al., 2002), on Somma-Vesuvius (Del Moro et al., 2001; Pappalardo et al., 2004) and Ischia (Piochi et al., 1999) eruptions have also highlighted that the variability of the Sr-isotope ratio can be explained by crustal contamination in a multidepth magmatic system. In these cases, magmas show an interaction with the wall-rocks because they contain crustal xenoliths (Campi Flegrei) and hornfelsed clasts (Somma-Vesuvius) with $\mathrm{Sr}$ isotope ratios $>0.708$ and sometimes show chemical and mineralogical disequilibria. Moreover, Pappalardo et al. (2002) showed that the Sr-isotopic ratios increase in the younger Campi Flegrei products as their residence time in the magmas chamber increases. Furthermore, crustal interaction is indicated by the negative correlation described by Campanian volcanics and crustal xenoliths on the classical isotope diagram of $\mathrm{Sr}$ and $\mathrm{Nd}$ (fig. 5a). Finally, crustal contamination for the Campanian magmas is suggested by the $\mathrm{La} / \mathrm{Nb}$ ratio which is always $>1$ (Thompson et al., 1984) and positively correlated to the $\mathrm{Sr}$ isotope ratio. Calculation based on the quantitative EC-AFC (Energy Conservation-Assimilation Fractional Crystallisation) approach that accounts for mass and energy conservation (Bohrson and Spera, 2001; Spera and Bohrson, 2001) indicates that the isotopic variations relative to the magmas feeding eruptions at Campi Flegrei and Somma-Vesuvius are explained by contamination with less than $40 \%$ of crustal rocks (Pappalardo et al., 2002, 2004).

Despite the evidence of crustal interaction, there is a wealth of papers which suggest the existence of a «crucial» Sr-isotopic value below which we can assume to deal with «mafic rocks». A correlation is observed between the $\mathrm{Sr}$-isotopic ratios of rocks and their crystallization depth at Somma-Vesuvius (Mastrolorenzo et al., 2003; Pappalardo et al., 2004). Olivines and pyroxenes from Somma-Vesuvius rocks crystallized at depths $>10 \mathrm{~km}$ (Belkin et al., 1985; Cortini et al., 1985; Belkin and De Vivo, 1993; Marianelli et al., 1999; Lima et al., 2003) have Sr-isotopic ratios lower than 0.7074 (Civetta and Santacroce, 1992; Ayuso et al., 1998, and references therein). These values are significantly different from those of the late-crystallized feldspars (crystallization depth $<5 \mathrm{~km}$; Belkin et al., 1985; Cortini et al., 1985; Belkin and De Vivo, 1993; Lima et al., 2003), with ${ }^{87} \mathrm{Sr} /{ }^{86} \mathrm{Sr}$ values around $0.7075-7$ (Civetta et al., 1991a; Civetta and Santacroce, 1992; Cioni et al., 1995; Ayuso et al., 1998, and references therein). Moreover, clinopyroxene cumulitic rocks from Somma-Vesuvius and Campi Flegrei (Ayuso et al., 1998 and references therein), display ${ }^{87} \mathrm{Sr} /{ }^{86} \mathrm{Sr}$ below 0.7065 . Pappalardo et al. (2002) exclude that the isotopic variations at Campi Flegrei are related to in situ radioactive growth, because a much longer time than that of the magmatic system ( $c a$. $60 \mathrm{kyr}$ ) would be required to produce the observed isotopic variability, and indicate that petrological variation not reflect mantle melting processes and/or mantle source(s) heterogeneity because the constancy of ratios between elements with similar degrees of incompatibility of the products. The authors, on the basis of a correlation between Sr-isotopic ratios and age, and of Sr-isotopic similarity between the least radiogenic rocks and the mantle xenoliths from Vulture, have linked the least contaminated magmas erupted at Campi Flegrei with those erupted before the Campanian Ignimbrite eruptions characterized by a Sr-isotopic ratios in the range $0.7067-0.7073$.

On the basis of these studies, we can choose as the least contaminated Campanian rocks those showing $\mathrm{Sr}$-isotopic ratios lower than 0.70735 . We can compare them with the mafic rocks from Procida and Ischia, which have ${ }^{87} \mathrm{Sr} /{ }^{86} \mathrm{Sr}$ widely below this limit and geochemical features akin to more primitive rocks.

\subsection{Primary magma compositions and the nature of mantle sources}

The possibility to discriminate the role of the shallow evolutionary processes (in particular crustal contamination) allow some representative mafic or near-mafic rocks to be investigated fur- 


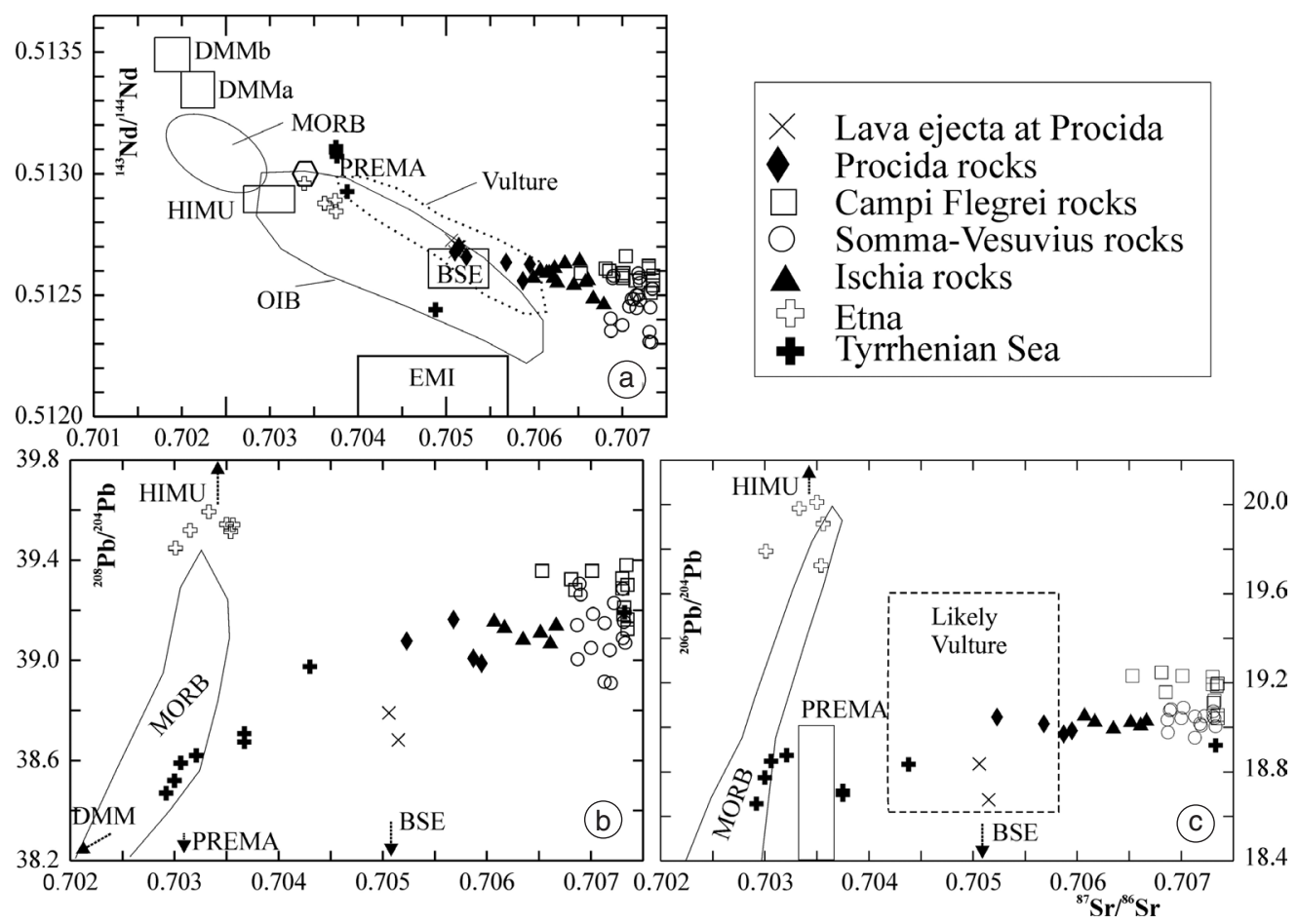

Fig. 5a-c. a) ${ }^{143} \mathrm{Nd} /{ }^{144} \mathrm{Nd}$, b) ${ }^{208} \mathrm{~Pb} /{ }^{204} \mathrm{~Pb}$, c) ${ }^{206} \mathrm{~Pb} /{ }^{204} \mathrm{~Pb}$ versus ${ }^{87} \mathrm{Sr} /{ }^{86} \mathrm{Sr}$ diagrams for selected Campanian magmas. Symbols: open crosses = Etna samples (Tanguy et al., 1997); full crosses = Tyrrhenian samples (Beccaluva et al., 1990; Gasperini et al., 2002); field for the Vulture mantle xenoliths (a) from Downes (2001) and hypothesized (c) on the basis of considerations from Downes (2001) and Dunai and Baur (1995). Other symbols as in fig. 2.

ther although they have variable $\mathrm{MgO}$ contents (3.8-10-11 wt \%). These rocks that approach or mirror the «original» geochemical and isotopical composition are those reported in figs. $3 \mathrm{a}, \mathrm{b}, 4 \mathrm{a}, \mathrm{b}$ and 5a-c. In the following, the Campanian rocks we have chosen will be compared with the transitional MORB-type basalts erupted in the contiguous sector of Tyrrhenian Basin (Vavilov Basin, sites 655 and 651 of ODP Leg. 107 and DSDP site 373, Leg. 42; Beccaluva et al., 1990; Gasperini et al., 2002) and with the intraplate basalts erupted on the opposite margin of the sea basin on the Sardinia coast (site 654).

The comparison among most mafic rocks from volcanic islands and from volcanoes located inland, as regards the major, REE and several trace elements pattern (figs. 2 and 3a,b) reveal some significant differences. At a given $\mathrm{SiO}_{2}$ content, Ischia and Procida magmas are enriched in $\mathrm{Ti}, \mathrm{Na}$, depleted in $\mathrm{La}, \mathrm{Ba}, \mathrm{Rb}, \mathrm{Sr}, \mathrm{Th}$, $\mathrm{K}$ contents, and show lower LREE/HFSE (e.g., $\mathrm{La} / \mathrm{Nb}=1-2$ ) with respect to the Campi Flegrei and Somma-Vesuvius magmas. Furthermore, LILE/HFSE ratios for rocks characterized by $\mathrm{MgO}$ exceeding 3.8\% increase moving west to east through the Campanian volcanic area (fig. $4 a, b)$. This trend is highlighted if we consider data (Beccaluva et al., 1990; Gasperini et al., 2002) for MORB-like magmas erupted in the contiguous sector of Tyrrhenian Basin (Vavilov Basin, sites 655 of ODP Leg. 107 and DSDP site 373, Leg. 42) that is also reported in fig. 4a,b.

The least contaminated Campanian samples define a unique trend when plotted in the ${ }^{87} \mathrm{Sr} /{ }^{86} \mathrm{Sr}$ versus ${ }^{143} \mathrm{Nd} /{ }^{144} \mathrm{Nd}$ diagrams (fig. 5a). Procida shoshonitic basalts have the lowest $\mathrm{Sr}$ 
ratios $(0.7050)$ and highest $\mathrm{Nd}(0.5128)$ ratios in the Campanian magmas, whereas the Campi Flegrei and Somma-Vesuvius rocks have the highest $\mathrm{Sr}$ ratios (0.7073) and the lowest Nd ratios (0.5126). Ischia magmas plot between these two compositions (fig. 5a). The Sr-isotopic differences are highlighted in ${ }^{87} \mathrm{Sr} /{ }^{86} \mathrm{Sr}$ versus ${ }^{206} \mathrm{~Pb} /{ }^{204} \mathrm{~Pb}$ diagrams (fig. $5 \mathrm{~b}, \mathrm{c}$ ).

As in fig. $4 a, b$, in these isotope-isotope diagrams (fig. 5a-c) we have also drawn the field for MORB-like magmas erupted in the contiguous sector of Tyrrhenian Basin (Vavilov Basin, sites 655 of ODP Leg. 107 and DSDP site 373, Leg. 42) interpreted as derived from an upwelling asthenospheric mantle (Beccaluva et al., 1990) probably having a plume-like imprint (Gasperini et al., 2002). In the $\mathrm{Sr}-\mathrm{Nd}$ isotope diagram (fig. 5a), the primitive magmas erupted at Procida plot between the Campi Flegrei and Somma-Vesuvius magmas and the Tyrrhenian magma field. This is supported also by $\mathrm{Sr}-\mathrm{Pb}$ trends (fig. 5b,c) where the relationship between the Tyrrhenian and the Campanian magmas is highlighted. Therefore, we consider the Tyrrhenian basalts as end-members for the isotopic trend of fig. 5a-c.

As we have excluded from the discussion the crustally contaminated rocks, we assume that the other end member is also located in the mantle domain. The trace element patterns of the Campanian magmas (fig. 3a,b) are similar to intraplate-magmas with respect to immobile elements $\mathrm{Zr}, \mathrm{Hf}, \mathrm{Ti}, \mathrm{Y}, \mathrm{Yb}$ and, at to a lesser extent, $\mathrm{Nb}$ but they are enriched in low ionic potential elements. Recent studies (Kostoula et al., 1999; Downes, 2001) suggest a lithospheric origin for the mantle xenoliths recovered in the volcanic products from Vulture Volcano located to the east of the Campanian Plain. These xenolith samples are geochemically and isotopically similar to the Campanian magmas (fig. 5a-c). On this basis we suggest that the other end member could be sub-continental enriched lithospheric mantle. In particular, the enrichment in the low ionic potential elements, especially $\mathrm{Rb}$ and $\mathrm{Ba}$, the small negative anomaly at $\mathrm{Nb}$, and the ratio between incompatible elements (e.g., $\mathrm{Th} / \mathrm{Yb}>2$ ) should be generated by the interaction with subduction related fluid as also suggested for the Vulture xenoliths

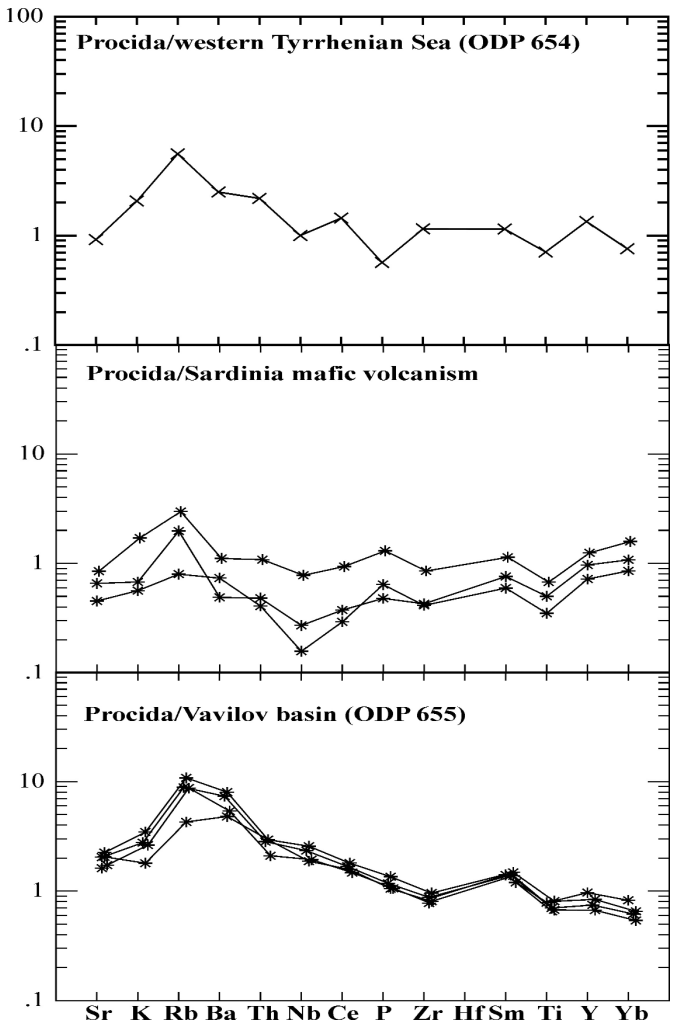

Fig. 6. Trace elements distribution for Procida mafic magmas normalized with respect to sample 654 from western margin of Tyrrhenian Sea (data from Beccaluva et al., 1990), to samples 655 from Vavilov Basin (data from Gasperini et al., 2002) and to samples from Sardinia mafic volcanism (data from Lustrino et al., 2000).

(Downes, 2001). Following Peccerillo and Manetti (1985) the higher K-enrichment of the most Somma-Vesuvius rocks with respect to the other Campanian rocks should be the consequence of melting at greater depths.

Trace element distributions and isotope compositions of the volcanic rocks from the islands (higher $\mathrm{Ti}$ and $\mathrm{P}$ content and lowest $\mathrm{Sr}-\mathrm{Pb}$ isotope ratios) compared with those from the mainland volcanoes, indicate that the asthenospheric contribution is more evident in the offshore volcanoes (Procida and Ischia) and it tends to vanish moving inland (Campi Flegrei and Somma- 
Vesuvius) where the lithospheric contribution becomes dominant. This can be a consequence of the progressive drop of the lithosphere-asthenosphere boundary moving from the Tyrrhenian Basin towards the Appennine Chain. Its depth varies from $25 \mathrm{~km}$ under the Tyrrhenian Basin, to $65 \mathrm{~km}$ beneath the Thyrrenian coast of Italy and finally up to a depth of $100 \mathrm{~km}$ under the Apenninic Chain (Cella et al., 1998).

To test this hypothesis we compared the primitive Procida magmas $(\mathrm{MgO}=11 \mathrm{wt} \%)$ with the anorogenic intraplate tholeiitic magmas erupted on the other border of Tyrrhenian Sea
$(\mathrm{MgO}=7 \mathrm{wt} \%)$, near the Sardinia coast (site 654), in the Vavilov Basin (site 655) and on the Sardinia Island (fig. 6). The similarity between Procida and Sardinia mafic rocks, also in term of $\mathrm{Sr}, \mathrm{Nd}$ and $\mathrm{Pb}$ isotope ratios (see Lustrino et al., 2000), as well as the similarity in immobile elements (i.e. $\mathrm{Sr}, \mathrm{Nb}, \mathrm{Zr}, \mathrm{Sm}, \mathrm{Yb}$ ) contents shown by Procida magmas and Tyrrhenian magmas, evidence that moving radially away from the basin toward its eastern (Italian Peninsula) and western (Sardinia Island) borders, the contribution of the asthenospheric MORB-type mantle decreases in favour of that of the «in-

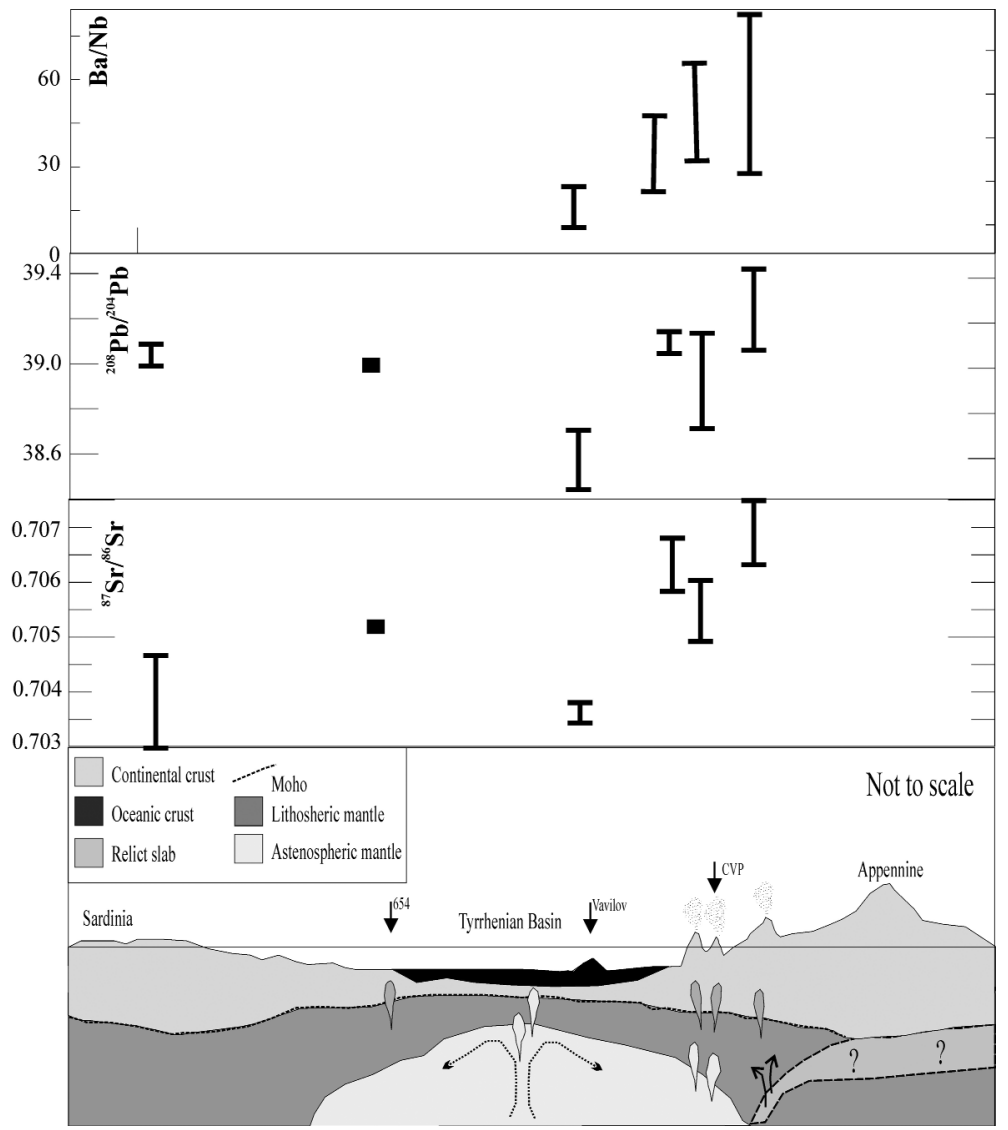

Fig. 7. Interpretative cross section from Tyrrhenian Sea towards the Campanian margin as indicated in fig. 1a,b. Chemical and isotopical variations moving from the Tyrrhenian Basin to the Campanian Comagmatic Province and to Sardinia are shown. 
traplate» lithospheric mantle. Furthermore, moving away from the Tyrrhenian Basin the contribution of subduction increases.

\section{Conclusions}

A spatial variation in chemical composition has been recognised among the volcanoes belonging to the Campanian Comagmatic Province (fig. 7). When the role of low-P evolution processes has been evaluated, the most primitive (not contaminated by crustal assimilation) rocks erupted from Procida and Ischia islands have: i) lower LILE/HFSE ratios with respect to those erupted at Campi Flegrei and Somma-Vesuvius. These ratios are insensitive to partial melting and fractionation processes and can be considered to be representative of the magmas source; ii) lower $\mathrm{Sr}, \mathrm{Pb}$ isotopic ratios and higher $\mathrm{Nd}$ isotopic ratios with respect to that of Campi Flegrei and Somma-Vesuvius.

These compositional variations can be explained assuming that both asthenospheric and «intra-plate» lithospheric mantle sources are involved in the genesis of the «primitive» magmas erupted in the Campania Comagmatic Region. The asthenospheric mantle, from which Tyrrhenian magmas were extracted, represents the deeper source. Moving from the Tyrrhenian abyssal plain to the Italian peninsula the contribution of enriched-lithospheric mantle became more pronounced in response to the increasing lithospheric thickness that magmas must cross en route to the surface (fig. 7 ).

The involvement of the lithosphere may be explained by geotherms uprising related to the asthenospheric upwelling. This hypothesis is supported by the presence of a low-velocity body underneath Somma-Vesuvius (De Natale et al., 2001) which extends from $15 \mathrm{~km}$ down to the upper mantle $(35 \mathrm{~km})$ and represents the presence of a partially molten body into the lithosphere.

\section{Acknowledgements}

We thank C. Hawkesworth, an anonymous reviewer and B. De Vivo that provided very helpful comments, greatly improving the man- uscript. We are also grateful to those people, although opposing the progression of our research, have contributed to increase our interest in volcanological and geochemical studies.

\section{REFERENCES}

Alessio, M., F. Bella, G. Belluomini, G. Calderoni, C. Cortesi, M. Fornaseri, M. Franco, F. Improta, A. SCHERILlo and B. Turi (1971): Datazioni con il metodo C-14 di carboni e di livelli humificati (paleosuoli) intercalati nelle formazioni piroclastiche dei Campi Flegrei (Napoli), Rend. Soc. It. Mineral. Petrol., 27 (2), 305-317.

Appleton, J.D. (1972): Petrogenesis of potassium-rich lavas from the Roccamonfina volcano, Roman region, Italy, J. Petrol., 13 (3), 425-456.

Ayuso, R.A., B. De Vivo, G. Rolandi, R.R. SEal II and A. PAONE (1998): Geochemical and isotopic (Nd-Pb-Sr-O) variations bearing on the genesis of volcanic rocks from Somma-Vesuvius, Italy, J. Volcanol. Geotherm. Res., 82, 53-78.

Beccaluva, L., P. Di Girolamo, V. Morra and F. Siena (1990): Phlegraean Fields volcanism revisited: a critical re-examination of deep-eruptive systems and magmas evolutionary processes, $N$. Jb. Geol. Paleont. Mh., H5, 257-271.

Beccaluva, L., P. Di Girolamo and G. Serri (1991): Petrogenesis and tectonic setting of Roman volcanic province, Italy, Lithos, 26, 191-221.

BelKIN, H.E. and B. DE VIVo (1993): Fluid inclusion studies of ejected nodules from plinian eruptions of Mt. Somma-Vesuvius, J. Volcanol. Geotherm. Res, 58, 98-100.

Belkin, H.E., B. De Vivo, E. Roedder and M. Cortin (1985): Fluid inclusion geobarometry from ejected Mt. Somma-Vesuvius nodules, Am. Mineral., 70, 288-303.

Belkin, H.E., C.R.J. KilbuRn and B. De Vivo (1993): Sampling and major element chemistry of the recent (A.D. 1631-1944 Somma-Vesuvius activity), J. Volcanol. Geotherm. Res., 58, 273-290.

BoHrson, W. and F.J. SPERA (2001): Energy-Constrained open-system magmatic processes, II. Application of Energy-Constrained Assimilation Fractional-Crystallization (EC-AFC). Model to magmatic systems, $J$. Petrol., 42, 1019-1041.

Brocchini, D., C. Principe, D. Castradori, M.A. LaURENZI and L. GORLA (2001): Quaternary evolution of the southern sector of the Campanian Plain and early Somma-Vesuvius activity: insights from the Trecase 1 well, Miner. Petrol., 73, 67-91.

Bruno, P.P., G. Cippitelli and A. Rapolla (1998): Seismic study of the Mesozoic carbonate basement around Mt. Somma-Vesuvius, Italy, J. Volcanol. Geotherm. Res., 84, 311-322.

Bruno, P.P., V. Di Fiore and G. Ventura (2000): Seismic study of the 41st Parallel Fault system offshore the Campanian-Latial continental margin, Italy, Tectonophysics, 324, 37-55.

Caprarelli, G., S. Togashi and B. De Vivo (1993): Preliminary $\mathrm{Sr}$ and $\mathrm{Nd}$ isotopic data for recent lavas from 
Somma-Vesuvius volcano, J. Volcanol. Geotherm. Res., 58, 377-381.

Cecchetti, A., P. Fulignati, P. Marianelli, N. Proto and A. Sbrana (2001): The feeding system of Campi Flegrei. Insights from melt and fluid inclusions on Ignimbrite Campana, Solchiaro and Minopoli eruptions, in GNV-INGV Assemblea, $1^{\circ}$ Anno, vol. abstracts, 190191.

Cella, F., M. Fedi, G. Florio and A. Rapolla (1998): Gravity modelling of the litho-asthenosphere system in the Central Mediterranean, Tectonophysics, 287, 117-138.

Cioni, R., L. Civetta, P. Marianelli, N. Metrich, R. SANTACROCE and A. SBRANA (1995): Compositional layering and syn-eruptive mixing of a periodically refilled shallow magmas chamber: the A.D. 79 plinian eruption of Somma-Vesuvius, J. Petrol., 36, 739-776.

Civetta, L. and R. SAntacroce (1992): Steady state magmas supply in the last 3400 years of Somma-Vesuvius activity, Acta Vulcanol., 2, 147-159.

Civetta, L., R. Galati and R. Santacroce (1991a): Magmas mixing and convective compo-sitional layering within the Somma-Vesuvius magmas chamber, Bull. Volcanol., 53, 287-300.

CivetTa, L., G. Gallo and G. ORSI (1991b): Sr- and Nd-isotope and trace-element constraints on the chemical evolution of the magmatic system of Ischia (Italy) in the last 55 kyr, J. Volcanol. Geotherm. Res., 46, 213-230.

Civetta, L., G. Orsi, L. Pappalardo, R.V. Fisher, G. HEIKEN and M. ORT (1997): Geochemical zoning, mingling, eruptive dynamics and depositional processes The Campanian Ignimbrite, Campi Flegrei caldera, Italy, J. Volcanol. Geotherm. Res., 75, 183-219.

CORRADO, G. and A. RAPOLla (1981): The gravity field of Italy: analysis of spectral composition and delineation of a tridimensional crustal model of Central-Southern Italy, Boll. Geofis. Teor. Appl., 89, 17-29.

Cortini, M. and O. Don Hermes (1981): Sr isotopic evidence for a multi source origin of the potassic magmas in the Neapolitan area (South Italy), Contrib. Mineral. Petrol., 77, 47-55.

Cortini, M., A. Lima and B. DE Vivo (1985): Trapping temperatures of melt inclusions from ejected Vesuvian maf ic xenoliths, J. Volcanol. Geotherm. Res., 26, 167-172.

Cundari, A. (1980): Role of subduction in the genesis of leucite-bearing rocks: facts on fashion?, Contrib. Mineral. Petrol., 73, 432-434.

D'Antonio, M. and P. Di Girolamo (1994): Petrological and geochemical study of mafic shoshonitic volcanics from Procida-Vivara and Ventotene islands (Campanian Region, South Italy), Acta Vulcanol., 5, 69-80.

D’Antonio, M., G.R. Tilton and L. CivetTa (1996): Petrogenesis of Italian alkaline lavas deduced from $\mathrm{Pb}-\mathrm{Sr}$ $\mathrm{Nd}$ isotope relationships, in Earth Processes: Reading the Isotopic Code, edited by A. BASU and S. HART, AGU Monogr. Ser., 95, 253-267.

D’antonio, M., L. Civetta, G. Orsi, L. Pappalardo, M. Piochi, A. CARANDEnTE, S. DE Vita, M. Di Vito and R. ISAIA (1999a): The present state of the magmatic system of the Campi Flegrei caldera based on a reconstruction of its behavior in the past $12 \mathrm{kyr}, J$. Volcanol. Geotherm. Res., 91, 247-268.

D’Antonio, M., L. CivetTa and P. Di Girolamo (1999b) Mantle source heterogeneity in the Campanian Region
(South Italy) as inferred from geochemical and isotopic features of mafic volcanic rocks with shoshonitic affinity, Mineral. Petrol., 67, 163-192.

D'Argenio, B., T. Pescatore and P. Scandone (1973): Schema Geologico dell'Appennino Meridionale (Campania e Lucania), in Atti del Convegno "Moderne vedute della geologia dell'Appennino», Accademia Nazionale dei Lincei, Roma, p. 183.

D'Argenio, B., F. Ortolani and T. Pescatore (1987): Geology of Southern Appennines: a brief outline, in Proc. Int. Symp. «Engineering Geology Problems in Seismic Areas», International Association of Engineering Geology, Bari, pp. 31.

De Astis, G., L. Pappalardo and M. Piochi (2004): Procida Volcanic History: new insights in the evolution of the Phlegraean Volcanic District (Campania Region, Italy), Bull. Volcanol., doi: 10.1007/s00445-004-0345-y.

De Natale, G., C. Troise, F. Pingue, P. De Gori and C. Chiarabba (2001): Sturcture and dynamics of the Somma-Vesuvius volcanic complex, Mineral. Petrol., 73, 5-22.

de Vita, S., G. Orsi, L. Civetta, A. Carandente, M. D'Antonio, A.L. Deino, T. Di Cesare, M.A. Di Vito, R.V. Fisher, R. Isaia, E. Marotta, M. Ort, L. PAPPAlardo, M. Piochi and J. Southon (1999): The Agnano-Monte Spina eruption $(4.1 \mathrm{kyr})$ in the resurgent, nested Campi Flegrei caldera (Italy), J. Volcanol. Geotherm. Res., 91, 269-301.

De Vivo, B., G. Rolandi, P.B. Gans, A. Calvert, W.A. Bohrson, F.J. Spera and H.E. Belkin (2001): New constraints on the pyroclastic eruptive history of the Campanian volcanic Plain (Italy), Mineral. Petrol., 73, 47-65.

Del Moro, A., P. Fulignati, P. Marianelli and A. Sbrana (2001): Magmas contamination by direct wall interaction: constraints from xenoliths from the walls of the carbonate-hosted magmas chamber (Somma-Vesuvius 1944 eruption), J. Volcanol. Geotherm. Res., 112, 1524.

Di Girolamo, P. (1978): Geotectonic setting of MioceneQuaternary volcanism in and around the Eastern Tyrrhenian Sea border (Italy) as deduced from major elements geochemistry, Bull. Volcanol., 41, 421-432.

Di Girolamo, P. (1987): Orogenic and anorogenic mantle source components in the anomalous post collisional peri-tyrrhenian volcanics (Italy), Boll. Soc. Geol. It., 103, 349-413.

DogLIONI, C. (1991): A proposal for kinematic modeling of W-dipping subductions-possible applications to the Tyrrhenian-Apennines system, Terra Nova, 3, 426-434.

Downes, H. (2001): Formation and Modification of the shallow sub-continental lithospheric mantle: a review of geochemical evidence from ultramafic xenolith suites and tectonically emplaced ultramafic massifs of western and central Europe, J. Petrol., 42 (1), 233-250.

DUNAI, T.J. and H. BAUR (1995): Helium, neon, argon systematics of the European subcontinental mantle: Implications for its geochemical evolution, Geochim. Cosmochim. Acta, 59 (13), 2767-2783.

Duschenes, J., K.E. Louden and M.C. SinHa (1986): A seismic refraction experiment in the Thyrrhenian Sea, Geophys. J. R. Astron. Soc., 85, 139-160.

Ellam, R.M., C.J. Hawkesworth, M.A. Menzies and W. 
RoGERS (1989): The volcanism of southern Italy: Role of subduction and relationship between potassic and sodic alkaline magmastism, J. Geophys. Res., 94, 4589-4601.

Ferrucci, F., G. Gaudiosi, N.A. Pino and G. Luongo (1989): Seismic detection of a major moho upheaval beneath the Campania volcanic area (Napoli, Southern Italy), Geophys. Res. Lett., 16 (11), 1317-1320.

FinetTI, I. and C. MoRELLI (1973): Geophysical exploration of the Mediterranean Sea, Boll. Geofis. Teor. Appl., 15, 263-341.

FinetTI, I. and C. Morelli (1974): Esplorazione sismica a riflessione nei Golfi di Napoli e Pozzuoli, Boll. Geofis. Teor. Appl., 16, 175-222.

Fulignati, P., A. Gioncada and A. Sbrana (1995): The magmas chamber related hydrothermal system of Somma-Vesuvius, first mineralogical and fluid inclusion data on hydrothermalized subvolcanic and lavic samples from phreatomagmatic eruptions, Period. Mineral., 64, 185-187.

Fulignati, P., P. Marianelli and A. Sbrana (1998): New insights on the thermometamorphic-metasomatic magmas chamber shell of the 1944 eruption of SommaVesuvius, Acta Vulcanol., 10 (1), 47-54.

Gasperini, D., J. Blichert-Toft, D. Bosch, A. Del Moro, P. MACERA and F. AlbarèDE (2002): Upwelling of deep mantle material through a plate window: Evidence from the geochemistry of Italian basaltic volcanics, $J$. Geophys. Res., 107, B12, 2367-2385.

Gilg, H.A., A. Lima, R. SOMma, R.A. Ayuso, H.E. Belkin and B. DE Vivo (1999): A fluid inclusion and isotope study of calc-silicate ejecta from Mt Somma-Vesuvius: evidence for interaction of high-temperature hypersaline fluids with the sedimentary basement, in Proceedings of ECROFI XV, Potsdam, Germany, abstracts and program, Terra Nostra, 99 (6), 118-120.

Gilg, H.A., A. Lima, R. Somma, H.E. Belkin, B. De Vivo and R.A. Ayuso (2001): Isotope geochemistry and fluid inclusion study of skarns from Somma-Vesuvius, Miner. Petrol., 73, 145-176.

Gillot, P.Y., S. Chiesa, G. Pasquarè and L. Vezzoli (1982): 33000 years K/Ar dating of the volcano-tectonic horst of the isle of Ischia, gulf of Naples, Nature, 229, 242-245.

Gueguen, E., C. Doglioni and M. Fernandez (1997): Lithospheric boudinage in the Western Mediterranean back-arc basin, Terra Nova, 9 (4), 184-187.

Hawkesworth, C.J. and R. Vollmer (1979): Crustal contamination versus enriched mantle: ${ }^{143} \mathrm{Nd} /{ }^{144} \mathrm{Nd}$ and ${ }^{87} \mathrm{Sr} /{ }^{86} \mathrm{Sr}$ evidence from the Italian volcanics, Contrib. Mineral. Petrol., 69, 151-165.

Ippolito, F., B. D'Argenio, T. Pescatore and P. ScAndone (1975): Structural-stratigraphic units and tectonic framework of Southern Appennines, in Geology of Italy, edited by C. SQuYRES (Lybian Society of Earth Science, Libyan Arab Republic), pp. 11.

Kostoula, T., A. Jones, H. Downes and A. Beard (1999): Geochemistry and isotopic composition of mantle xenoliths from Vulture Volcano, S. Italy, Ofioliti, 24 (1a), 120 .

LaVecchia, G. (1988): The Tyrrhenian Appenines system: structural setting and seismo-tectogenesis, Tectonophysics, 147, 263-296.
Lima, A., L.V. Danyushevsky, B. De Vivo and L. Fedele (2003): A model for the evolution of the Mt. SommaVesuvius magmatic system based on fluid and melt inclusion investigations, in Melt Inclusions in Volcanic Systems: Methods, Applications and Problems, Developments in Volcanology Series, edited by B. DE VIVO and R.J. BODNAR, 227-249.

Lustrino, M., L. Melluso and V. Morra (2000): The role of lower continental crust and lithospheric mantle in the genesis of Plio-Pleistocene volcanic rocks from Sardinia (Italy), Earth Planet. Sci. Lett., 180, 259-270.

Marianelli, P., N. Métrich and A. Sbrana (1999): Shallow and deep reservoirs involved in magmas supply of the 1944 eruption of Somma-Vesuvius, Bull. Volcanol., 61, 48-63.

Mastrolorenzo, G., L. Pappalardo and M. Piochi (2003): The 3700 BP-1944 A.D. magmas chambers of SommaVesuvius: review and new hypothesis, in Proceedings of the EGS 28th General Assembly, Nice, France, 7-11 (submitted).

NAKAMURA, N. (1974): Determination of REE, Ba, Fe, Mg, $\mathrm{Na}$ and $\mathrm{K}$ in carbonaceous and ordinary chondrites, Geochim. Cosmochim. Acta, 38, 757-73.

Orsi, G., G. Gallo, G. Heiken, G. wohletz, E. Yu and G. BONANI (1992): A comprehensive study of pumice formation and dspersal: the Cretaio Tephra of Ischia (Italy), J. Volcanol. Geotherm. Res., 53, 329-354.

Orsi, G., L. Civetta, M. D'Antonio, P. Di Girolamo and M. PIOCHI (1995): Step-filling and development of a threelayer magmas chamber: the Neapolitan Yellow Tuff case history, J. Volcanol. Geotherm. Res., 67, 291-312.

Orsi, G., S. DE VITA and M. Di Vito (1996): The restless, resurgent Campi Flegrei nested caldera (Italy): constraints on its evolution and configuration, J. Volcanol. Geotherm. Res., 74, 179-214.

Pappalardo, L., L. Civetta, M. D'Antonio, A.L. Deino, M.A. Di Vito, G. Orsi, A. Carandente, S. DE Vita, R. IsAiA and M. PIOCHI (1999): Chemical and isotopical evolution of the Phlegraean magmatic system before the Campanian Ignimbrite (37 kyr) and the Neapolitan Yellow Tuff (12 kyr) eruptions, J. Volcanol. Geotherm. Res., 91, 141-166.

Pappalardo, L., M. Piochi, M. D'Antonio, L. Civetta and R. PETRINI (2002): Evidence for multi-stage magmatic evolution during the past $60 \mathrm{kyr}$ at Campi Flegrei (Italy) deduced from $\mathrm{Sr}, \mathrm{Nd}$ and $\mathrm{Pb}$ isotope data, $J$. Petrol., 43 (7), 1415-1434.

Pappalardo, L., M. Piochi and G. Mastrolorenzo (2004): The 3550 year BP-1944 A.D. magma-plumbing system of Somma-Vesuvius: constraints on its behaviour and present state through a review of $\mathrm{Sr}-\mathrm{Nd}$ isotope data, Ann. Geophys., 47 (4), 1471-1483 (this volume).

PAterne, M., F. Guichard and J. LABEYRIE (1988): Explosive activity of the south Italian volcanoes during the past 80000 years as determined by marine tephrochronology, J. Volcanol. Geotherm. Res., 34, 153-172.

PeArCE, J.A. (1983): The role of sub-continental lithosphere in magmas genesis at destructive plate margins, in Continental Basalts and Mantle Xenoliths, edited by C.J. HawkesworTh and M.J. NorRY (Nantwich, Schiva), pp. 14.

PeCCERILLO, A. (1990): On the origin of the Italian potassic magmas-comments, Chem. Geol., 85, 183-196. 
PeCCERILlo, A. (1999): Multiple mantle metasomatism in central-southern Italy: geochemical effects, timing and geodynamic implications, Geology, 27, 315-318.

PeCCERILlo, A. (2001): Geochemical similarities between the Somma-Vesuvius, Phlegraean Fields and Stromboli volcanoes: petrogenetic, geodynamic and volcanological implications, Mineral. Petrol., 73 (1-3), 93-105.

Peccerillo, A. and P. Manetti (1985): The potassic alkaline volcanism of central Southern Italy: a review of the data relevant to petrogenesis and geodinamic significance, Trans. Geol. Soc. S. Afr., 88, 379-394.

Perfit, M.R., D.A. Gust, A.E. Bence, R.J. Arculus and S.R. TAYLOR (1980): Chemical characteristics of island arc basalts: implications for mantle sources, Chem. Geol., 30, 277-256.

Piochi, M., L. CivetTA and G. ORSI (1999): Mingling in the magmatic system of Ischia (Italy) in the past $5 \mathrm{kyr}$ Mineral. Petrol., 66 (4), 227-258.

Rosi, M. and A. SBranA (1987): The Phlegraean Fields, Quad. Ric. Sci., 114 (9), pp. 176.

Rosi, M., A. Sbrana and L. Vezzoli (1988): Stratigrafia delle isole di Procida e Vivara, Boll. GNV, IV, 500-525.

Santacroce, R., A. Bertagnini, L. Civetta, P. LANDi and A. SBRANA (1993): Eruptive dynamics and petrogenetic processes in a very shallow magmas reservoir: the 1906 eruption of Somma-Vesuvius, J. Petrol., 34, 383425.

SAVELLI, C. (1968): The problem of rock assimilation by Somma-Vesuvius magmas, II. Compositions of sedimentary rocks and carbonate ejecta from SommaVesuvius area, Contrib. Mineral. Petrol., 18, 43-64.

SAVELLI, D. and F.C. WeZEL (1979): Morfologia e stile tettonico del bacino tirrenico, in Atti del Convegno $S_{C}$. Naz. PF-CNR Oceanografia e Fondi Marini, Roma, 2 729-738.

SCANDONE, P. (1979): Origin of the Tyrrhenian sea and Calabrian arc, Boll. Soc. Geol. It., 98, 27-34.

SCANDONE, P. (1982): Structure and evolution of the Calabrian Arc, Earth Evol. Sci., 2 (3), 172-180.

SchuTte, K.G. (1978): Crustal structure of southern Italy, in Alps, Apennines and Hellenides, edited by H. CLoss, D.R. RoEDER and K. SCHMIDT (Scweizerbart, Stuttgart, Germany), 315-327.

SERri, G., F. INNOCENTI and P. MANETti (1993): Geochemical and petrological evidence of the subduction of delaminated Adriatic continental lithosphere in the genesis of the Neoge-Quaternary magmastism of central
Italy, Tectonophysics, 223, 117-147.

Somma, R., R.A. Ayuso, B. DE Vivo and G. Rolandi (2001): Major, trace element and isotope geochemistry (Sr-Nd$\mathrm{Pb}$ ) of interplinian magmas from Mt. Somma-Vesuvius (Southern Italy), Mineral. Petrol., 73, 121-143.

SPADINI, G. and F.C. WeZEL (1994): Exploration Seismology (Cambridge University Press, Cambridge), 2nd edition, pp. 419

SPERA, F.J. and W.A. Bohrson (2001): Energy-constrained open-system magmatic processes, I. General model and Energy-Constrained Assimilation and Fractional Crystallization (EC-AFC) formulation, J. Petrol., 42 (5), 9991018.

TANGuY, J.C., F. Condomines and G. KiefFer (1997): Evolution of the Mount Etna magmas: Constraints on the present feeding system and eruptive mechanism, $J$. Volcanol. Geotherm. Res., 75 (3/4), 221-250.

Thompson, R.N., M.A. Morrison, G.L. Hendry and S.J. PARRY (1984): An assessment of the relative roles of a crust and mantle in magmas genesis: an elemental approach, Phil. Trans. R. Soc. London, A310, 549-590.

Thorpe, R.S., P.W. Francis and L. Ò'CALlanghan (1984): Relative role of source composition, fractional crystallisation and crustal contamination in the petrogenesis of Andean volcanic rocks, Phil. Trans. R. Soc. Lond., A310, 675-692.

TURI, B. and H.P. TAYLOR (1976): Oxygen isotope studies of potassic volcanic rocks of the Roman Province, Central Italy, Contrib. Mineral. Petrol., 55, 1-31.

Vezzol, L. (1988): Island of Ischia, Quad. Ric. Sci., 114 (10), pp. 134.

VOLLMER, R. (1976): Rb-Sr and U-Th-Pb systematics of the alkaline rocks from Italy, Geochim. Cosmochim. Acta, 40, 283-295.

VOLLMER, R. (1989): On the origin of the potassic magmas, I. A discussion contribution, Chem. Geol., 74, 229-239.

Vollmer, R., K. Johnston, M.R. GHiara, L. LiRER and R. MunNo (1981): Sr isotope geochemistry of megacrysts from continental rift and converging plate margin alkaline volcanism in south Italy, J. Volcanol. Geotherm. Res., 11, 317-327.

Zollo, A., P. Gasparini, J. Virieux, H. Le Meur, G. De Natale, G. Biella, E. Boschi, P. Capuano, R. De Franco, P. Dell'Aversana, R. De Matteis, I. Guerra, G. IanNACCONE, L. Mirabile and G. Vilardo (1996): Seismic evidence for a low-velocity zone in the upper crust beneath Somma-Vesuvius, Science, 274, 592-594. 